\title{
Building Information Modelling in Indonesia: Knowledge, Implementation and Barriers
}

\author{
Andreas F Van Roy and *Adrian Firdaus
}

\begin{abstract}
First submission: 21 January 2020; Accepted: 30 May 2020; Published: 15 December 2020
To cite this article: Andreas F Van Roy and Adrian Firdaus (2020). Building Information Modelling in Indonesia: Knowledge, implementation and barriers. Journal of Construction in Developing Countries, 25(2): 199-217. https://doi.org/10.21315/ jcdc2020.25.2.8.
\end{abstract}

To link to this article: https://doi.org/10.21315/jcdc2020.25.2.8

\begin{abstract}
This article aims to identify the status of construction industry practitioners in Indonesia in terms of their knowledge and current practices as well as the barriers for implementing Building Information Modelling (BIM). This study utilises a questionnaire survey, aimed at the construction industry practitioners in Indonesia. The result shows that BIM is still a novelty for the construction practitioners in Indonesia. This is backed with the finding that more than $60 \%$ of the respondents was not familiar with BIM terminology or did not have proper knowledge of BIM terminology. More than $70 \%$ of the respondents' projects have implemented BIM Level 1 , mostly in transportation service, energy production and distribution, roads and bridges, and the building infrastructure category. The five highest ranks of barriers to BIM implementation are lack of BIM training, lack of BIM experience and capability, no client demand, high cost in software and hardware acquisition, and inadequate information technology (IT) facilities. The recommended strategy should be initiated by the government, by conducting a comprehensive familiarisation programme covering BIM knowledge, BIM advantages and BIM implementation in the industry. At the same time, the government should prepare regulations and standards as guidance to BIM implementation in Indonesia.
\end{abstract}

Keywords: Building Information Modelling, Information technology, Implementation, Maturity level, Barrier

\section{INTRODUCTION}

Throughout the construction project life cycle, a huge amount of data is generated, stored, communicated and transferred among project stakeholders. Different specialists from many disciplines interact and corporate to generate and utilise such data. According to Levinet (1988), such interaction and corporation require a structured and organised approach, helped by the use of computers. As construction projects are becoming larger and more complex these days, and the Internet is being used more and more, the use of information and communication technology (ICT) is inevitable for structuring and organising these huge amounts of data.

For the last two decades, the use of ICT has been increasing rapidly. This is due to the capability of ICT to improve the efficiency and effectiveness of business processes (O'Brien and Marakas, 2010). Therefore, it is common practice for today's business managers to use tablet computers to coordinate work and conduct decision-making (Laudon and Laudon, 2013). However, Peansupap and Walker (2004), Feng (2006), Chassiakos (2007), Ahuja, Yang and Shankar (2010)

Civil Engineering Department, Universitas Katolik Parahyangan, Bandung, INDONESIA

*Corresponding author: adrianfirdaus@unpar.ac.id 
and JBKnowledge (2016) found that the construction industry as one of the oldest industries shows progress in adapting ICT in their construction processes. Betts (1999), Peansupap and Walker (2004), Gallaher et al. (2004) in Succar (2009), Feng (2006), Chassiakos (2007), Ahuja, Yang and Shankar (2010) and JBKnowledge (2016) explain that there are several barriers that hinder the adoption of ICT. Among others, there is the fragmentation of the construction industry in term of ways of operation, high investment for the hardware, software and brain-ware without clear evaluation of these investments, and also the lack of interoperability and standardisation.

In light of this slow adoption of ICT and the improvement of the efficiency and effectiveness of business processes in the construction industry, a new approach of operation is needed. Amor et al. (2002) mentioned three major themes as future directions of ICT implementation in construction industries based on the Working Commission 78 (W78) of the CIB (International Council for Innovation and Research in Construction): (1) visual and standardisation modelling of processes and integration throughout the project life cycle, (2) management of technology concerning adoption, implementation and behaviour, and (3) re-engineering the processes including the integrated supply chains.

Those three themes in the new approach are matched with Building Information Modelling (BIM) as the recent and most promising development in the construction industry. BIM supports the design through the complete project life cycle among project stakeholders. In addition, BIM facilitates the construction process as well as operation and maintenance (Eastman et al., 2011). According to Succar (2009), BIM is able to reduce fragmentation of the construction industries, improve the efficiency/effectiveness of the business process and raise the level of interoperability.

Even though BIM provides promising results to overcome the barriers that hinder the adoption of ICT as well as improve the efficiency and effectiveness of the construction business process, the adoption of BIM is not an easy task (Chai et al., 2017). According to Smith (2014), the number of countries that successfully developed the strategies for BIM implementation include the United Kingdom (UK), North America and countries in the Scandinavian region. Nevertheless, Arayici et al. (2011) found the challenges in implementing BIM remain, such as the resistance to change the process of work among stakeholders as well as the requirement of high-end hardware and network facilities.

According to Sahil (2016), the challenging issues in adopting BIM are the same whether faced by developed or developing countries. For example, in Malaysia, Bin Zakaria et al. (2013) found that construction industry players in Malaysia are confused about where, when and how to start implementing BIM as national BIM guidelines and standards are not available. Virulrak (2016) mentioned that two major issues emerged in Thailand construction industry in implementing BIM; first, about the misperception of BIM as just a tool instead of a development process and second, the high cost of migration. In addition, as for Thailand's construction industry, Ngowtanasuwan and Hadikusumo (2017) found that lack of executives with appropriate knowledge and understanding is a bottleneck for BIM adoption. Because Indonesia is one of the developing countries, this article aims to identify the status of the construction industry practitioners in Indonesia in terms of their knowledge and current practices as well as the barriers to BIM implementation. 


\section{LITERATURE REVIEW}

The literature review covers three main targets of this study, namely knowledge, implementation and the barriers of BIM. The knowledge of BIM is identified in accordance with the literature review of the definition of BIM. The implementation of BIM is investigated based on the study of BIM's maturity level. The barriers of BIM implementation are observed using several barrier factors, which have been studied previously.

\section{BIM Definition}

National BIM Standard-United States ${ }^{\circledR}$ (2015) defined BIM as "a digital representation of physical and functional characteristics of a facility. As such, it serves as a shared knowledge resource for information about a facility, forming a reliable basis for decisions during its life cycle from inception onward". Zuppa, Issa and Suermann (2009) defined BIM as a concept to improve collaboration between each party in a construction project, aiming to control any project-related risk as well as achieving the project's objective. McGraw Hill (2009) emphasised that BIM utilisation covers the design, construction, operation and maintenance phase of a construction project. In terms of the design phase, BIM is implied as "an intelligent three-dimensional (3D) virtual building model that can be constructed digitally by containing all aspects of building information - into an intelligent format that can be used to develop optimised building solutions with reduced risk and increase value before committing to a design proposal" (Woo, Wilsmann and Kang, 2010: 538).

In accordance with those definitions, it could be summarised that BIM is a collaboration concept between each party in construction projects using a digital model, which allows building data distribution to reduce any risk in the entire project life cycle.

\section{BIM Maturity Level}

Succar (2010: 291) describes the BIM maturity level as "the quality, repeatability and degree of excellence within a BIM capability". As stated by Succar (2009), the BIM maturity level consists of three levels, which are BIM Level 1: Object-based modelling, BIM Level 2: Model-based collaboration and BIM Level 3: Network-based integration. Besides, Succar (2010) adds the Pre-BIM Level, which accommodates the construction industry before the implementation of BIM (Succar, 2010).

\section{Barriers to BIM Implementation}

Various studies have discussed the barriers to BIM implementation in both developed and developing countries. Liu et al. (2015) identify 12 factors as barriers to BIM implementation. Those 12 factors had been adopted from 18 research papers published between 2004 and 2014. Based on those factors, the top three factors which are considered as barriers are the high cost of application, lack of national standards and lack of skilled personnel. The surveys have also been conducted in China and Australia. 
As the Australian architecture, engineering and construction (AEC) industry has established the BIM standard, the Chinese AEC industry is at an early stage of promotion of BIM, so there is a slight difference in the detail rank of those three factors. The Chinese respondents focused on the high cost of application whilst the Australian focused on the lack of national standards.

Hosseini et al. (2016) in 2015 conducted a survey on Iranian construction practitioners to identify the barriers to BIM implementation. Based on 13 factors adopted from 12 research papers published between 2010 and 2015, it was found that the five main factors are lack of support by policy makers, ignorance about where to start and training being unavailable, BIM standards being unavailable and the cost to purchase the software. Considering Iran as a developing country like Malaysia, research conducted by Bin Zakaria et al. (2013) for the Malaysian AEC industry found almost similar result, where the practitioners do not know where to start as there are no BIM guidelines and standards due to the lack of government support and the people show resistance to change.

The research related to the BIM implementation in the Middle East was conducted by Gerges et al. (2017), who found 10 factors as barriers and obstacles to implementing BIM. The top five derived from 10 factors are: the practitioners compare BIM with computer-aided design (CAD), resistance to change, BIM as additional cost, lack of BIM specialists and lack of demand.

Moreover, NBS (National Building Specifications) as a leading institution in the UK that monitors the BIM implementation not just in the UK but also in Canada, Finland and New Zealand, found that the top four barriers are lack of expertise, lack of standardised tools and protocol, lack of collaboration and cost (NBS, 2013). On the other hand, in the NBS (2014), focusing only on the UK, the top five barriers are: (1) no client demand, (2) BIM being not always relevant to the projects worked on, (3) cost, (4) the projects worked on are seen as too small and (5) lack of in-house expertise (NBS, 2014).

In the NBS (2018), 17 main barriers are identified to implementing BIM. Among those barriers, the top five consists of lack of in-house expertise, no client demand, lack of training, BIM being not relevant to the projects worked on, cost and no time to get up to speed while Ahmed in 2018 conducted research in Bangladesh found that top five barrier to implementation of BIM are social and habitual resistance to change, traditional methods of contracting, training expenses and the learning curve are too expensive, high cost of software purchasing and lack of awareness about BIM.

Based on all those research results both in developed and developing countries, several factors appear several times such as cost, lack of BIM standard, lack of expertise, lack of government support, lack of necessary training, no client demand and resistance to change. Table 1 shows the map of BIM implementation barriers. 
Building Information Modelling in Indonesia

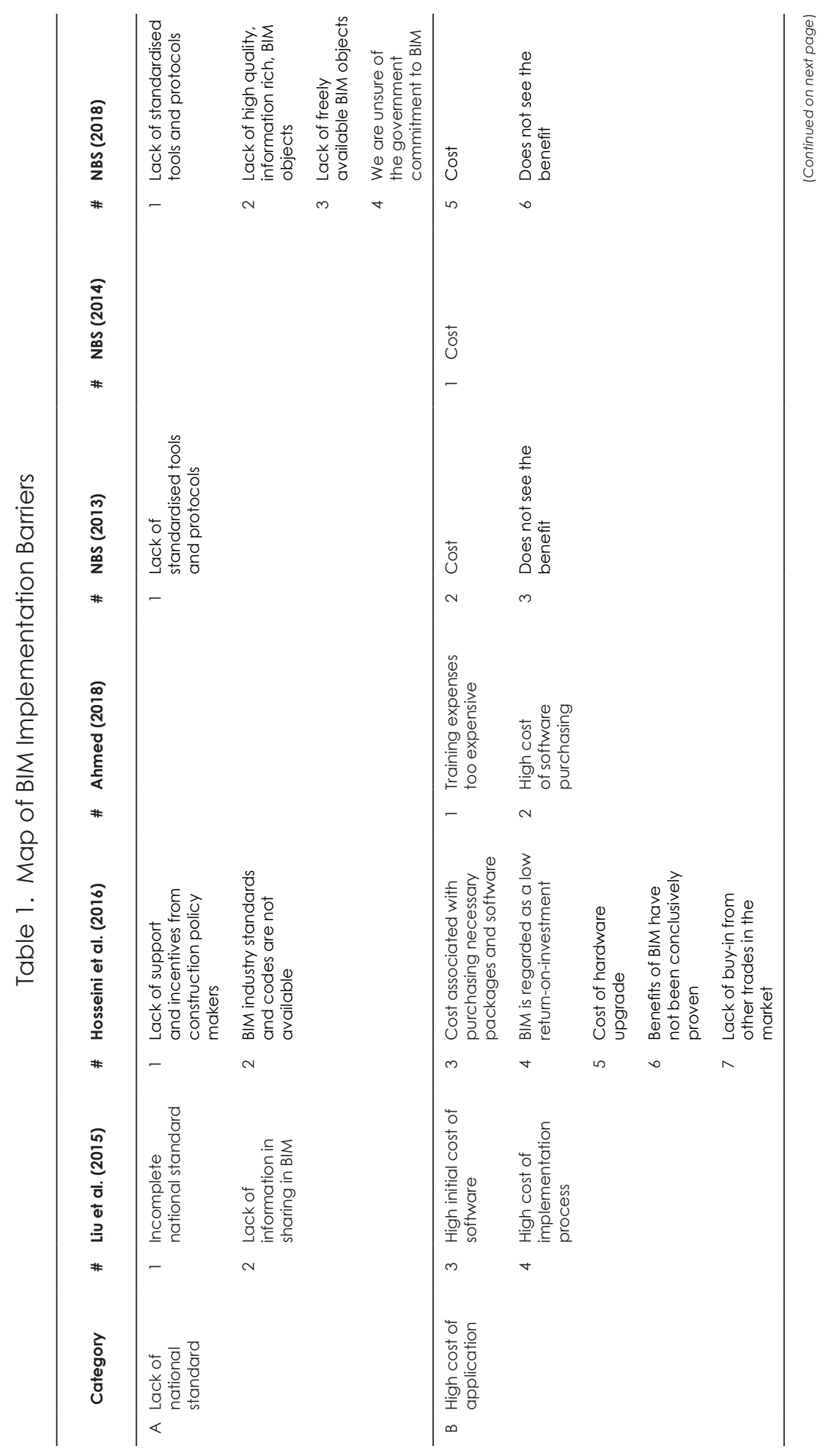


Andreas F Van Roy and Adrian Firdaus

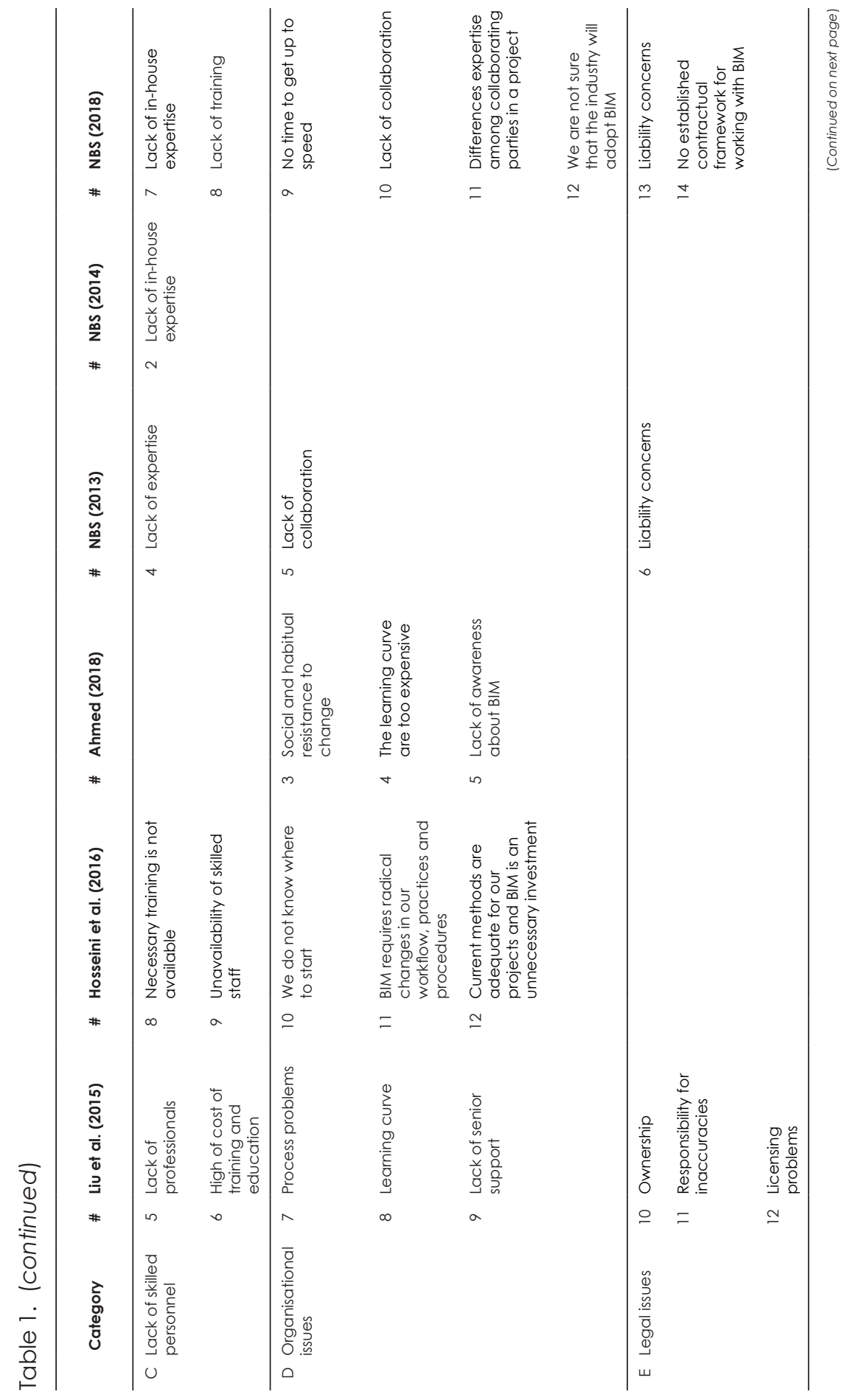


Building Information Modelling in Indonesia

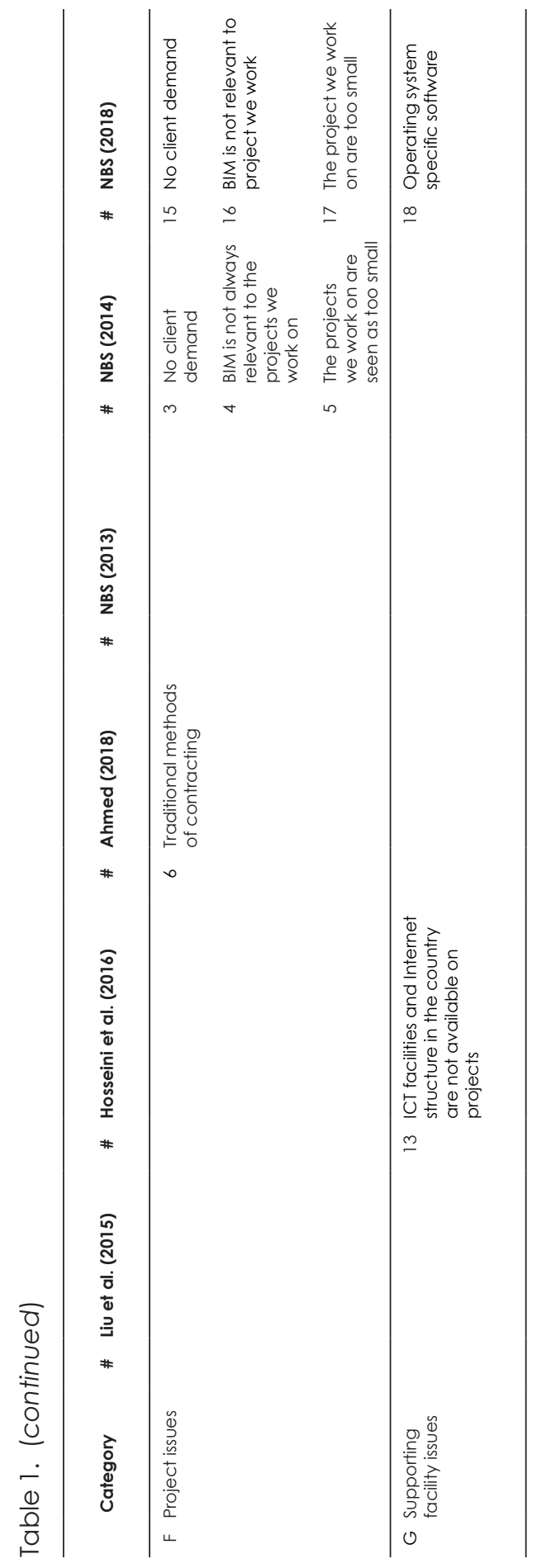

PENERBIT UNIVERSITI SAINS MALAYSIA/205 


\section{METHODOLOGY}

This study utilises a questionnaire survey covering four main sections, which are: (1) the profile of respondents and projects, (2) knowledge of BIM, (3) implementation of BIM and (4) barriers to BIM implementation. The questionnaire section combines both open and closed questions, aiming at the infrastructure practitioners in Indonesia.

\section{Profile of Respondents and Projects}

This section identifies the profile of respondents, including type of company, project and experience. The type of company includes owner, consultant or contractor, alongside with the sub-qualification of the company (in accordance with the Ministry of Public Works of the Republic of Indonesia Regulation No. 8 of 2011 concerning division of sub-classification and sub-qualification of constructions services business). The experience categories range from 0 to 5 years, 5 to 10 years, 10 to 15 years and more than 15 years. Furthermore, this section identifies the detail of the project in which the respondent is involved. The detail covers the infrastructure category (Grigg, 1988) and the project life cycle, in accordance with BIM Project Life Cycle Phases 1, 2 and 3 (Succar, 2009).

Succar (2009) delivered three different project life cycle phases, which differ in the overlapping between three project stages (design, construction and operation). As described by Succar (2009), Phase 1 shows no overlapping between any of project stages. Phase 2 presents an overlap between the design and construction stages, while all project stages overlapped each other in Phase 3. These project life cycle phases are related to the BIM maturity level, in which each level could optimally be beneficial in the respective life cycle. These life cycle phases are shown to the respondents to identify which phase could best describe the project they are currently working on.

\section{Knowledge of BIM}

The investigated knowledge includes BIM basic definition and BIM maturity level. The questions include filter questions, aimed at sorting the characteristics of the respondents. The filter questions guide the respondents to answer the question based on their knowledge, meaning that respondents do not need to answer all the questions. The questions lead to four different groups of respondents, which differ in the knowledge of BIM terminology and maturity level. The groups are:

1. Group 1: The respondent who was not familiar with BIM terminology or did not have a correct knowledge of BIM terminology.

2. Group 2: The respondent who had a correct knowledge of BIM terminology but was not familiar with the BIM maturity level.

3. Group 3: The respondent who had a correct knowledge of BIM terminology was familiar with BIM maturity level but did not give a correct explanation about the BIM maturity level.

4. Group 4: The respondent who had a correct knowledge of BIM terminology was familiar with BIM maturity level and gave a correct explanation about the BIM maturity level. 
The first question (Q1) investigates whether the respondent is familiar with BIM terminology. If the respondent is not familiar with BIM terminology, they will be directed to the next section (BIM Implementation) and classified as Group 1, otherwise they continue to the second question (Q2).

The second question investigates the respondent's knowledge of BIM's basic definition, whether it is classified as computer software or as a collaboration concept. If the respondents choose computer software, they will be directed to the next section (BIM Implementation) and classified as Group 1, otherwise they continue to the third question (Q3).

The third question investigates knowledge of the BIM maturity level. If the respondents do not know about this maturity level, they will be directed to the next section (BIM Implementation) and classified as Group 2, otherwise, they continue to the fourth question (Q4). In the following question, the respondents will be asked to explain their knowledge of BIM maturity level through an open question. If the answer is wrong (in accordance with the literature by Succar [2009] regarding the BIM maturity level), the respondents will be classified as Group 3, otherwise, they will be classified as Group 4.

\section{Implementation of BIM}

The output of this section is the BIM maturity level of the project the respondent is currently working on. In the first question in this section (Q5), the respondents are asked to identify the dimension of the model used in their project. If the project still utilised only the two-dimensional (2D) model, then the BIM maturity level of the project is classified as Pre-BIM and the respondent will be directed to the next section. If the answer is 3D model or combination of $2 \mathrm{D}$ and $3 \mathrm{D}$, the respondent will be directed to the next question.

The second question in this section (Q6) identifies whether the utilised model includes the cost and time (scheduling) parameter. If the answer is "No", the BIM maturity level of the project will be classified as BIM Level 1 and the respondent will be directed to the next section. If the cost and time parameter included in the model, the respondent will be directed to the next question. In the third question in this section (Q7), the respondent is asked if all stakeholders work in one model. The BIM maturity level of the project will be classified as BIM Level 2 if the answer is "No". If all stakeholders work in one model, the project is classified as BIM Level 3. After this question, the respondent will be directed to the next section.

\section{Barriers to BIM Implementation}

As mentioned earlier in the Literature Review section, especially in barriers to BIM implementation part (refer to Table 1), several factors appear several time with the different phrase but the same meaning. For example, "incomplete national standard" mentioned by Liu et al. (2015) and "lack of support and incentive from construction policy" mentioned by Hosseini et al. (2016). In this article, a new phrase is established to include all the meanings. For the example mentioned before, the phrase is "No government regulations and standards". The similar mechanism applied to all factors mentioned by all those researches. As the final list, 14 BIM implementation barriers can be seen on Table 11. 
The respondent is asked to rate the significance of 14 BIM implementation barriers using the Likert scale of 1 to 5 (ranging from not important to very important). The response will then be ranked using the relative importance index (RII) method to identify the most important barrier to BIM implementation. A brief explanation of BIM terminology, maturity level, implementation example and requirements are given as a preface to this section, in order to assist the respondent who was not familiar with BIM.

\section{RESULTS AND DISCUSSION}

The questionnaire is distributed to 150 construction practitioners in Indonesia, resulting in 112 responses. The distribution was conducted from March to December 2018. The results of each section which is followed by the respective discussion are presented as follows.

\section{Profile of Respondents and Projects}

The respondents consist of contractors, consultants and owners of Indonesian construction industries. Most of the respondents work as consultant, with the value of $48 \%$ of total respondents, followed by $35 \%$ of owners and $17 \%$ of contractors.

Among the respondent who works as consultant, $87 \%$ of the respondent works in a company which is allowed to execute project without any size limit, $9 \%$ in approximately USD165,000 limit and 4\% in approximately USD30,000 limit. In between the respondent who works as contractor, $58 \%$ of the respondent works in a company which is allowed to execute project without any size limit and both $21 \%$ in approximately USD 16,650,000 and USD3,300,000 limit. The experience length of the respondents, followed by infrastructure category and project life cycle phase of the project of the respondents are described in Tables 2 and 3, respectively.

In accordance with the profile shown in Tables 2 and 3, the experience length of the respondents varies in each category. It means that the response is obtained from a balanced point of view. Most of their current projects are building, energy production and distribution (including oil and gas facilities), and road and bridge projects. It indicates that most of the projects are considered complex in the design, construction and operation phases.

Table 2. Experience Length of the Respondent

\begin{tabular}{lcc}
\hline Experience & Amount & $\%$ \\
\hline 0 to 5 years & 23 & 20.5 \\
5 to 10 years & 38 & 33.9 \\
10 to 15 years & 39 & 34.8 \\
$>15$ years & 12 & 10.7 \\
\hline Total & 112 & 100.0 \\
\hline
\end{tabular}


Related to project life cycle category, most of the respondents defined the project life cycle phase of the project they were working on as Phase 1. It means that most of the projects have no overlap between project stages. Only $40 \%$ of the respondents experienced an overlap between the design and construction stages, while the rest of the respondents worked on a project which has a full overlap between the design, construction and operation stage.

Table 3. Project Life Cycle Phase Based on Infrastructure Category

\begin{tabular}{lcccc}
\hline Infrastructure Category & Phase 1 & Phase 2 & Phase 3 & Amount \\
\hline Transportation service & 8 & 1 & - & 9 \\
Energy production and distribution & 12 & 17 & 2 & 31 \\
Roads and bridges & 16 & 5 & 2 & 23 \\
Buildings & 17 & 19 & 2 & 38 \\
Water management & 7 & 1 & - & 8 \\
Waste management & 1 & 2 & - & 3 \\
\hline Total & 61 & 45 & 6 & 112 \\
\hline Total percentage & 54 & 40 & 5 & 100 \\
\hline
\end{tabular}

Source: Based on Succar (2009)

\section{Knowledge of BIM}

In accordance with the BIM knowledge group explained in the previous section, the percentage of each group is presented in Table 4.

Table 4. Knowledge Group of Respondents

\begin{tabular}{lcc}
\hline Knowledge Group & Amount & $\%$ \\
\hline 1 & 70 & 63 \\
2 & 28 & 25 \\
3 & 12 & 11 \\
4 & 2 & 2 \\
\hline Total & 112 & 100.0 \\
\hline
\end{tabular}

According to Table 4, more than $60 \%$ of the respondents belongs to Group 1, who was not familiar with BIM terminology or did not have a correct knowledge of BIM terminology. There are $25 \%$ of respondents that belongs to Group 2, indicating that they apprehend BIM as a collaboration concept but are not familiar with the BIM maturity level while $11 \%$ of the respondents understands BIM terminology but gives a wrong explanation about the BIM maturity level. Only $2 \%$ of the respondents belong to Group 4, which was familiar with the BIM maturity level and gave a correct explanation about the BIM maturity level. This could lead to the conclusion that BIM is still a novelty for the construction practitioners in Indonesia. 
Such finding is near similar to the Iran construction industry as well as in the Middle East. Hosseini et al. (2016) found that only $29.5 \%$ involved in some level of BIM, while Gerges et al. (2017) found only $20 \%$ in the Middle East are using BIM or in the process of adopting. A similarity of conditions was also portrayed when a survey was conducted in the UK in 2010 when the BIM journey is started. Although different on percentage, it seems this becomes the pattern when BIM on the early stages of the journey.

Table 5 shows that BIM Knowledge Groups 3 and 4 only belong to the category indicating 0 to 5 and 5 to 10 years' experience. It indicates that the respondents ranging from the younger category have more up-to-date knowledge of the latest construction technology compared to the elder one. Thus, the recommendation is to conduct a knowledge transfer within the company, since the elder category is involved more in stakeholder interfacing, in which BIM could potentially solve the interfacing problems.

Table 5. BIM Knowledge Group Based on Respondent's Experience Length

\begin{tabular}{|c|c|c|c|c|c|c|c|c|c|c|}
\hline \multirow{2}{*}{$\begin{array}{l}\text { Experience } \\
\text { Length }\end{array}$} & \multicolumn{2}{|c|}{ Group 1} & \multicolumn{2}{|c|}{ Group 2} & \multicolumn{2}{|c|}{ Group 3} & \multicolumn{2}{|c|}{ Group 4} & \multicolumn{2}{|c|}{ Total } \\
\hline & Amount & $\%$ & Amount & $\%$ & Amount & $\%$ & Amount & $\%$ & Amount & $\%$ \\
\hline 0 to 5 years & 9 & 39 & 5 & 22 & 8 & 35 & 1 & 4 & 23 & 100 \\
\hline 5 to 10 years & 24 & 63 & 9 & 24 & 4 & 11 & 1 & 3 & 38 & 100 \\
\hline 10 to 15 years & 28 & 72 & 11 & 28 & - & - & - & - & 39 & 100 \\
\hline$>15$ years & 9 & 75 & 3 & 25 & - & - & - & - & 12 & 100 \\
\hline Total & 70 & 63 & 28 & 25 & 12 & 11 & 2 & 2 & 112 & 100 \\
\hline
\end{tabular}

Table 6 shows that BIM Knowledge Groups 3 and 4 only belong to transportation service, energy production and distribution, and the building infrastructure category. Thus, it could be concluded that the respondent who works on these three categories has the best BIM knowledge. Furthermore, based on the respondent's company in Table 7, there is no owner found to belong to Groups 3 or 4 . This finding could relate to the next analysis of BIM implementation barriers.

Table 6. BIM Knowledge Group Based on Infrastructure Category

\begin{tabular}{|c|c|c|c|c|c|c|c|c|c|c|}
\hline \multirow{3}{*}{$\begin{array}{l}\text { Infrastructure Category } \\
\text { Transportation service }\end{array}$} & \multicolumn{2}{|c|}{ Group 1} & \multirow{2}{*}{\multicolumn{2}{|c|}{$\begin{array}{c}\text { Group } 2 \\
\text { Amount \% }\end{array}$}} & \multicolumn{2}{|c|}{ Group 3} & \multicolumn{2}{|c|}{ Group 4} & \multicolumn{2}{|c|}{ Total } \\
\hline & \multirow{2}{*}{$\frac{\text { Amount }}{2}$} & \multirow{2}{*}{$\begin{array}{l}\% \\
22\end{array}$} & & & \multirow{2}{*}{$\frac{\text { Amount }}{1}$} & \multirow{2}{*}{$\frac{\%}{11}$} & \multirow{2}{*}{ Amount } & \multirow{2}{*}{$\%$} & \multirow{2}{*}{$\frac{\text { Amount }}{9}$} & \multirow{2}{*}{$\begin{array}{c}\% \\
100\end{array}$} \\
\hline & & & 6 & 67 & & & & & & \\
\hline $\begin{array}{l}\text { Energy production and } \\
\text { distribution }\end{array}$ & 19 & 61 & 2 & 6 & 9 & 29 & 1 & 3 & 31 & 100 \\
\hline Roads and bridges & 17 & 74 & 6 & 26 & - & - & - & - & 23 & 100 \\
\hline Buildings & 26 & 68 & 9 & 24 & 2 & 5 & 1 & 3 & 38 & 100 \\
\hline Water management & 4 & 50 & 4 & 50 & - & - & - & - & 8 & 100 \\
\hline Waste management & 2 & 67 & 1 & 33 & - & - & - & - & 3 & 100 \\
\hline Total & 70 & 63 & 28 & 25 & 12 & 11 & 2 & 2 & 112 & 100 \\
\hline
\end{tabular}


Table 7. BIM Knowledge Group based on the Company of Respondents

\begin{tabular}{|c|c|c|c|c|c|c|c|c|c|c|}
\hline \multirow{2}{*}{ Company } & \multicolumn{2}{|c|}{ Group 1} & \multicolumn{2}{|c|}{ Group 2} & \multicolumn{2}{|c|}{ Group 3} & \multicolumn{2}{|c|}{ Group 4} & \multicolumn{2}{|l|}{ Total } \\
\hline & Amount & $\%$ & Amount & $\%$ & Amount & $\%$ & Amount & $\%$ & Amount & $\%$ \\
\hline Owner & 25 & 64 & 14 & 36 & - & - & - & - & 39 & 100 \\
\hline Consultant & 33 & 61 & 9 & 17 & 10 & 19 & 2 & 4 & 54 & 100 \\
\hline Contractor & 12 & 63 & 5 & 26 & 2 & 11 & - & - & 19 & 100 \\
\hline Total & 70 & 63 & 28 & 25 & 12 & 11 & 2 & 2 & 112 & 100 \\
\hline
\end{tabular}

\section{Implementation of BIM}

More than $70 \%$ of the project of the respondent has implemented BIM Level 1. There are still $17 \%$ of projects that implemented the Pre-BIM Level, in which paperbased documentation occurs. Compared to the BIM knowledge result, it could be concluded that Indonesian construction practitioners have implemented BIM Level 1 without having a proper knowledge of BIM. These findings could lead to an immediate need to conduct BIM familiarisation programme for Indonesian construction practitioners in order to leave the Pre-BIM Level and fully implement at least BIM Level 1 in their project.

Table 8 shows that transportation service, energy production and distribution, roads and bridges, and building infrastructure category in which the respondents are working, implement a higher BIM maturity level. The transportation service category even presents no project under Pre-BIM level. There are several projects that still implement the Pre-BIM level, including roads and bridges, water management and waste management. This finding is supported by the fact that the project within those categories has a relatively low level of complexity.

Table 8. BIM Implementation Based on Infrastructure Category

\begin{tabular}{|c|c|c|c|c|c|c|c|c|c|c|}
\hline \multirow{2}{*}{ Infrastructure Category } & \multicolumn{2}{|c|}{ Pre-BIM } & \multicolumn{2}{|c|}{ Level 1} & \multicolumn{2}{|c|}{ Level 2} & \multicolumn{2}{|l|}{ Level 3} & \multicolumn{2}{|c|}{ Total } \\
\hline & Amount & $\%$ & Amount & $\%$ & Amount & $\%$ & Amount & $\%$ & Amount & $\%$ \\
\hline Transportation service & - & - & 7 & 78 & 2 & 22 & - & - & 9 & 100 \\
\hline $\begin{array}{l}\text { Energy production } \\
\text { and distribution }\end{array}$ & 3 & 10 & 27 & 87 & 1 & 3 & - & - & 31 & 100 \\
\hline Roads and bridges & 9 & 39 & 10 & 43 & 4 & $17 \%$ & - & - & 23 & 100 \\
\hline Buildings & 1 & 3 & 34 & 89 & 3 & 8 & - & - & 38 & 100 \\
\hline Water management & 4 & 50 & 3 & 38 & 1 & 13 & - & - & 8 & 100 \\
\hline Waste management & 2 & 67 & 1 & 33 & - & - & - & - & 3 & 100 \\
\hline Total & 19 & 17 & 82 & 73 & 11 & 10 & - & - & 112 & 100 \\
\hline
\end{tabular}

In accordance with the result shown in Table 9, most of the respondents who work as contractors and consultants have already implemented BIM Level 1. Pre-BIM implementation is found mostly among respondents who work at owner-companies. This fact could reflect the finding on BIM implementation barriers, which states that "no client demand" is one of the most important barriers. The implementation of BIM 
is subsequently compared to the investigated project life cycle phase (based on Succar [2009]) which has been discussed in the previous chapter. The result of the comparison is provided in the Table 10.

Table 9. BIM Implementation Based on the Company of Respondents

\begin{tabular}{|c|c|c|c|c|c|c|c|c|c|c|}
\hline \multirow{2}{*}{ Company } & \multicolumn{2}{|c|}{ Pre-BIM } & \multicolumn{2}{|c|}{ Level 1} & \multicolumn{2}{|c|}{ Level 2} & \multicolumn{2}{|c|}{ Level 3} & \multicolumn{2}{|c|}{ Total } \\
\hline & Amount & $\%$ & Amount & $\%$ & Amount & $\%$ & Amount & $\%$ & Amount & $\%$ \\
\hline Owner & 17 & 44 & 18 & 46 & 4 & 10 & - & - & 39 & 100 \\
\hline Consultant & 1 & 2 & 50 & 93 & 3 & 6 & - & - & 54 & 100 \\
\hline Contractor & 1 & 5 & 14 & 74 & 4 & 21 & - & - & 19 & 100 \\
\hline Total & 19 & 17 & 82 & 73 & 11 & 10 & - & - & 112 & 100 \\
\hline
\end{tabular}

Table 10. Comparison between Project Life Cycle Phase and BIM Implementation

\begin{tabular}{lcc}
\hline Category & Amount & $\%$ \\
\hline Project life cycle phase = BIM implementation & 39 & 34.8 \\
Project life cycle phase < BIM implementation & 7 & 6.3 \\
Project life cycle phase > BIM implementation & 66 & 58.9 \\
\hline Total & 112 & 100.0 \\
\hline
\end{tabular}

Based on Table 10, the most identified category is "Project life cycle phase > BIM implementation" by $58.9 \%$. This category means that the respective project requires a higher BIM maturity level implementation. This leads to a recommendation of accelerating the BIM familiarisation programme so that all parties could understand the potential benefit of a particular BIM maturity level implementation in a specific project life cycle phase.

\section{Barriers to the Implementation of BIM}

The ranked barriers to BIM implementations based on all answers are depicted in Table 11.

Table 11. The Overall Rank of BIM Implementation Barriers

\begin{tabular}{ccl}
\hline Rank & Factor Number & Factor \\
\hline 1 & 7 & Lack of BIM training \\
2 & 6 & Lack of BIM experience and capability \\
3 & 13 & No client demand \\
4 & 3 & High cost software and hardware acquisition \\
5 & 14 & Inadequate information technology (IT) facilities \\
\hline
\end{tabular}

(Continued on next page) 
Table 11. (continued)

\begin{tabular}{ccl}
\hline Rank & Factor Number & Factor \\
\hline 6 & 1 & No government regulations and standards \\
7 & 5 & High cost user training \\
8 & 2 & No government incentive \\
9 & 9 & Project complexity \\
10 & 11 & Responsibility for BIM implementation failure \\
11 & 8 & Project delivery method \\
12 & 12 & License problem potential \\
13 & 4 & BIM is regarded as a low return-on-investment \\
14 & 10 & Ownership problem potential \\
\hline
\end{tabular}

Most of the high ranks are derived from BIM knowledge problems (lack of BIM training and lack of BIM experience and capability) and BIM cost problem (high cost of software and hardware acquisition). Those problems could be more severe due to the other high barrier ranks which indicate no government regulations and standards. Although different in order, these three barriers were consistent with the findings of several researchers. As shown in Table 1, Hosseini et al. (2016), Liu et al. (2015) and NBS (2013) found that lack of national standard and support from the government as the first barrier. These three researchers also put the cost issues for BIM application includes in the top three barriers. However, in terms of training issues as well as the experience and the capability, the order of barrier is different for Hosseini et al. (2016) and Liu et al. (2015). They found this barrier included in the order of the fifth to the ninth. It seems the factor of information disclosure in the globalisation era triggers the Indonesian construction industry to more eager to learn the BIM compare to wait for regulations as well as the national standard. Moreover, this finding related to the culture issue where knowledge and education as critical factors in motivating project participants in the implementation of BIM. Such finding in line with research results of Musa et al. that published on 2018.

The rank generated based on buildings, energy production and distribution, and the consultant specific respondent group, shows that "no client demand" is the highest barrier rank. This result is in line with the previous findings concerning respondents who work as owners: (1) mostly belong to BIM Knowledge Group 1, who was unfamiliar with BIM terminology (2) mostly involved in projects that still implement Pre-BIM Level. This leads to a priority in accelerating BIM "penetration" to the owner entities within Indonesian construction industry. Once the owners have fully understood the BIM terminology, benefits and implementation, they could obligate BIM implementation in their projects, pushing all other stakeholders to do so.

Being considered as the biggest owner entity, the government should initiate the "penetration" process by conducting a national familiarisation programme. This should be initially conducted internally, e.g., of the government, to ensure that all governmental functionaries have the same understanding of BIM terminology and benefits. The familiarisation programme will then be continued to the private entities, including owners, contractors and consultants. The programme should 
be performed in phases, considering the wide region of Indonesia and the inert nature of the Indonesian construction industry. The programme is aimed mainly introducing the benefits of BIM in all project phases. The understanding of BIM benefits could enhance the shifting of the traditional viewpoint of practitioners in which, certainly, BIM implementation is certainly considered costly. All BIM benefits include enhancing productivity and improving collaboration. It could potentially save much of the cost compared to its installation. Besides, BIM implementation could escalate the company value from the marketing point of view, since BIM has been common practice in many countries.

In parallel, government should establish respective regulations and standards for BIM implementation. Through the regulation, the government could necessitate BIM implementation for all public project gradually, in line with the execution of the familiarisation programme. Indonesian government has established the regulation through the regulation of Ministry of Public Works and Public Housing of the Republic of Indonesia Number 22/2018 concerning construction of government buildings. This regulation stated that BIM must be implemented in government buildings with more than 2,000 $\mathrm{m}^{2}$ area and more than two floors. Moreover, this regulation stated that the design output is produced using BIM, covering architectural drawing, structural drawing, utility drawing, landscape drawing, bill of quantity and cost estimation.

In order to enhance the implementation, this scope of the regulation should be gradually expanded to all construction projects in Indonesia. Besides, it should be backed with more detail regulation derivative, consisting a comprehensive standard in order to keep the BIM implementation on the right track. The standard could be adapted from a developed country, in which BIM has been implemented maturely. The standard should consider the suitability of the required BIM implementation and the project's complexity. The project's complexity could be categorised based on the project resource budget, number of stakeholders, or project significance. Then the category could be matched with the suitable BIM maturity level implementation. Additionally, the government should consider giving an incentive to accelerate the implementation. This could enhance small scale company to start learning and implementing BIM in their projects.

\section{CONCLUSION}

In summary, BIM is still novel for the construction practitioner in Indonesia. This is supported by the finding that more than $60 \%$ of the respondents was not familiar with BIM terminology or did not have correct knowledge of BIM terminology. Only $2 \%$ of the respondents was familiar with BIM maturity level and gave a correct explanation about maturity level. In terms of experience length of the respondents, this percentile belongs to the 0 to 5 and 5 to 10 years' experience category. Based on the infrastructure category, $2 \%$ of respondents mostly work in transportation service, energy production and distribution, and building infrastructure category.

More than $70 \%$ of the projects of the respondents have implemented BIM Level 1, mostly in the fields of transportation service, energy production and distribution, roads and bridge, and building infrastructure category. There are still $17 \%$ of projects that implemented the Pre-BIM Level, in which paper-based documentation occurs. Compared to the BIM knowledge result, it could be concluded that Indonesian construction practitioners have implemented BIM 
Level 1 without having a proper knowledge of BIM. Compared to the life cycle phase of their current project, almost $60 \%$ of the projects of the respondents require a higher BIM maturity level implementation.

The five highest ranks of barriers to BIM implementation are lack of BIM training, lack of BIM experience and capability, no client demand, high cost of software and hardware acquisition, and inadequate IT facilities. The recommended strategy should be initiated by the government, by conducting a comprehensive familiarisation programme covering BIM knowledge, BIM advantages and BIM implementation in the industry. The cognition of BIM advantages could change the conventional presumption about the high cost of BIM implementation. All BIM advantages such as escalating productivity and improving collaboration. This could potentially save much of the cost compared to BIM procurement costs. Additionally, BIM implementation could escalate the company value from the marketing point of view.

At the same time, government should prepare regulations and standards for BIM implementation. The government could oblige BIM implementation for all public projects gradually through the regulation. Indonesian government has launched the regulation through the Ministry of Public Works and Public Housing of the Republic of Indonesia Regulation No. 22. This regulation obligated BIM implementation in every government building with more than $2,000 \mathrm{~m}^{2}$ area and more than two floors. The regulation should be supported with a comprehensive standard in order to guide the BIM implementation. The standard could be adapted from a developed country, where BIM has been implemented maturely. In addition, the government should also consider giving an incentive to accelerate the implementation. This could enhance the small scale companies to start learning and implementing BIM in their projects.

\section{REFERENCES}

Ahmed, S. (2018). Barriers to implementation of Building Information Modeling (BIM) to the construction industry: A review. Journal of Civil Engineering and Construction, 7(2): 107-113. https://doi.org/10.32732/jcec.2018.7.2.107.

Ahuja, V., Yang, J. and Shankar, R. (2010). Perceptions affecting ICT adoption for building project management in the Indian construction industry. International Journal of Construction Management, 10(2): 1-18. https://doi .org/10.1080/15623599.2010.10773141.

Amor, R., Betts, M., Coetzee, G. and Sexton, M. (2002). Information technology for construction: Recent work and future directions. ITcon, 7: 245-258.

Arayici, Y., Coates, P., Koskela, L., Kagioglou, M., Usher, C. and OReilly, K. (2011). BIM adoption and implementation for architectural practices. Structural Survey, 29(1): 7-25. https://doi.org/10.1108/026308011111118377.

Betts, M. (1999). Strategic Management of IT in Construction. Oxford: Blackwell Science Ltd.

Bin Zakaria, Z., Mohamed Ali, N., Tarmizi Haron, A., Marshall-Ponting, A.J. and Abd Hamid, Z. (2013). Exploring the adoption of Building Information Modelling (BIM) in the Malaysian construction industry: A qualitative approach. IJRET: International Journal of Research in Engineering and Technology, 2(8): 384-395. https://doi.org/10.15623/ijret.2013.0208060. 
Chai, C., Tan, C.S., Aminudin, E., Loo, S.C., Goh, K.C., Theong, M.C., Lee, X.S. and Chin, L.W. (2017). The potential cost implications and benefits from Building Information Modeling in Malaysian construction industry. Paper presented at the ASIA International Multidisciplinary Conference 2017. Johor, Malaysia, 1-2 May.

Chassiakos, A.P. (2007). The use of information and communication technologies in construction. In B.H.V. Topping (ed.), Civil Engineering Computations: Tools and Techniques. Stirlingshire, Scotland: Saxe-Coburg Publications, 888-889.

Eastman, C., Teicholz, P., Sacks, R. and Liston, K. (2011). BIM Handbook: A Guide to Building Information Modeling for Owners, Managers, Designers, Engineers, and Contractors. 2nd Ed. Hoboken, NJ: John Wiley and Sons, Inc.

Feng, Y.P. (2006). Application of information technology in construction management. In The CRIOCM 2006 International Symposium on "Advancement of Construction Management and Real Estate". Salford, UK: CIB (International Council for Research and Innovation in Building and Construction).

Gallaher, M.P., O'Connor, A.C., Dettbarn Jr, J.L. and Gilday, L.T. (2004). Cost Analysis of Inadequate Interoperability in the US Capital Facilities Industry. Maryland, US: National Institute of Standards and Technology, US Department of Commerce Technology Administration.

Gerges, M., Austin, S., Mayouf, M., Ahiakwo, O., Jaeger, M., Saad, A. and Gohary, T. (2017). An investigation into the implementation of Building Information Modeling in the Middle East. ITcon, 22: 1-15.

Government of Indonesia (2018). Ministry of Public Works and Public Housing of the Republic of Indonesia Regulation No. 22 of 2018 Concerning Construction of Government Buildings. Jakarta: Government of Indonesia.

. (2011). Ministry of Public Works of the Republic of Indonesia Regulation No. 8 of 2011 Concerning Division of Sub-Classification and Sub-Qualification of Constructions Services Business. Jakarta: Government of Indonesia.

Grigg, N.S. (1988). Infrastructure Engineering and Management. Hoboken, NJ: John Wiley and Sons, Inc.

Hosseini, M.R., Azari, E., Tivendale, L., Banihashemi, S. and Chileshe, N. (2016). Building Information Modeling (BIM) in Iran: An exploratory study. Journal of Engineering, Project and Production Management, 6(2): 78-89. https://doi.org/10.32738/JEPPM.201607.0002.

JBKnowledge (2016). The 5th Annual 2016 Construction Technology Report. Texas: JBKnowledge in partnership with Mechanical Contractors Association of America, Construction Financial Management Association and the Texas A\&M University Construction Science Department.

Laudon, K.C. and Laudon, J.P. (2013). Essentials of Management Information Systems. 10th Ed. Essex, England: Pearson Education, Inc.

Levinet, H.A. (1988). Computer in project management. In D.I. Cleland and W.R. King (eds.), Project Management Handbook. 2nd Ed. Hoboken, NJ: John Wiley and Sons, Inc.

Liu, S., Xie, B., Tivendal, L. and Liu, C. (2015). Critical barriers to BIM in the AEC industry. International Journal of Marketing Studies, 7(6): 162-171. https://doi.org/10.5539/ijms.v7n6pl62.

McGraw Hill (2009). The business value of BIM: Getting to the bottom line. Available at: http://www.bim.construction.com/research/2009 [Accessed on 15 June 2018]. 
Musa, S., Marshall-Ponting, A., Nifa, F.A.A. and Shahron, S.A. (2018). Building Information Modeling (BIM) in Malaysian construction industry: Benefits and future challenges. Proceedings of the 3rd International Conference on Applied Science and Technology (ICAST'18). New York: AIP Publishing. https://doi.org/10.1063/1.5055507.

National BIM Standard-United States ${ }^{\circledR}(2015)$. National BIM Standard-United States ${ }^{\circledR}$ Fact Sheet. Vermont Avenue, NW: National BIM Standard-United States®.

NBS (National Building Specifications) (2018). National BIM Report 2018. Newcastle Upon Tyne, UK: RIBA Enterprises Ltd.

. (2014). National BIM Report 2014. Newcastle Upon Tyne, UK: RIBA Enterprises Ltd.

(2013). National BIM Report 2013. Newcastle Upon Tyne, UK: RIBA Enterprises Ltd.

Ngowtanasuwan, G. and Hadikusumo, B.H.W. (2017). System dynamics modelling for BIM adoption in Thai architectural and engineering design industry. Construction Innovation, 17(4): 457-474, https://doi.org/10.1108/Cl-03-2016 $-0018$.

O'Brien, J.A. and Marakas, G.M. (2010). Introduction to Information Systems. 15th Ed. New York: McGraw-Hill/Irwin.

Peansupap, V. and Walker, D.H.T. (2004). Strategic adoption of information and communication technology (ICT): Case studies of construction contractors. In F. Khosrowshahi (ed.), 20th Annual ARCOM Conference, 1-3 September 2004, Heriot Watt University. Vol. 2. Edinburgh, UK: Association of Researchers in Construction Management (ARCOM), 1235-1245.

Sahil, A.Q. (2016). Adoption of Building Information Modeling in developing countries: A phenomenological perspective. MSc diss. Colorado State University.

Smith, P. (2014). BIM implementation: Global strategies. Procedia Engineering, 85: 482-492, https://doi.org/10.1016/j.proeng.2014.10.575.

Succar, B. (2010). The five components of BIM performance measurement. In Special Track 18th CIB World Building Congress. Salford, UK: CIB. https://doi.org/10.13140/2.1.3357.1521.

. (2009). Building Information Modelling framework: A research and delivery foundation for industry stakeholders. Automation in Construction, 18(3): 357375. https://doi.org/10.1016/j.autcon.2008.10.003.

Virulrak, P. (2016). The business of Building Information Modeling: Case study of Thailand. Proceeding of the 16th International Conference on Computing in Civil and Building Engineering (ICCCBE2016). Osaka, Japan: ICCCBE2016 Organizing Committee, 895-902.

Woo, J., Wilsmann, J. and Kang, D. (2010). Use of as-built Building Information Modelling. In J. Ruwanpura, Y. Mohamed and S. Lee (eds.), Construction Research Congress 2010: Innovation for Reshaping Construction Practice. Reston, VA: American Society of Civil Engineers. https://doi.org/10.1061/41 109(373)54.

Zuppa, D., Issa, R.R.A. and Suermann, P.C. (2009). BIM's impact on the success measures of construction projects. In C.H. Caldas and W.J. O'Brien (eds.), Computing in Civil Engineering. Reston, VA: American Society of Civil Engineers. https://doi.org/10.1061/9780784410523. 